\title{
Preparation and Characterization of Super-Absorbing Gel Formulated from k-Carrageenan-Potato Peel Starch Blended Polymers
}

\author{
Mahmoud Moustafa ${ }^{1,2, *}$, M. A. Abu-Saied ${ }^{3}{ }^{(D}$, Tarek H. Taha ${ }^{4}{ }^{\mathbb{D}}$, Mohamed Elnouby $^{5}$, Eman A. El Desouky ${ }^{6}$, \\ Saad Alamri ${ }^{1,7}$, Ali Shati ${ }^{1}$, Sulaiman Alrumman ${ }^{1}{ }^{(D}$, Huda Alghamdii ${ }^{1}{ }^{(D}$, Mohmed Al-Khatani ${ }^{1}$, \\ Rahmah Al-Qthanin 1,7 (D) and Ahmed Al-Emam ${ }^{8,9}$
}

check for updates

Citation: Moustafa, M.; A. Abu-Saied, M.; H. Taha, T.; Elnouby, M.; A. El Desouky, E.; Alamri, S.; Shati, A.; Alrumman, S.; Alghamdii, H.; Al-Khatani, M.; et al. Preparation and Characterization of

Super-Absorbing Gel Formulated from $\mathrm{k}$-Carrageenan-Potato Peel Starch Blended Polymers. Polymers 2021, 13, 4308. https://doi.org/ $10.3390 /$ polym 13244308

Academic Editors: Farayde Matta Fakhouri and José Ignacio Velasco

Received: 8 November 2021 Accepted: 6 December 2021 Published: 9 December 2021

Publisher's Note: MDPI stays neutral with regard to jurisdictional claims in published maps and institutional affiliations.

Copyright: (c) 2021 by the authors. Licensee MDPI, Basel, Switzerland. This article is an open access article distributed under the terms and conditions of the Creative Commons Attribution (CC BY) license (https:// creativecommons.org/licenses/by/ $4.0 /)$
1 Department of Biology, College of Science, King Khalid University, Abha 9004, Saudi Arabia; saralomari@kku.edu.sa (S.A.); aaalshati@kku.edu.sa (A.S.); salrumman@kku.edu.sa (S.A.); hudaghamdi@kku.edu.sa (H.A.); dr.malkahtani@gmail.com (M.A.-K.); rngerse@kku.edu.sa (R.A.-Q.)

2 Department of Botany and Microbiology, Faculty of Science, South Valley University, Qena 83523, Egypt

3 Polymer Materials Research Department, Advanced Technology and New Materials Research Institute, City of Scientific Research and Technological Applications (SRTA-City), Alexandria 21934, Egypt; mouhamedabdelrehem@yahoo.com

4 Environmental Biotechnology Department, Genetic Engineering and Biotechnology Research Institute (GEBRI), City of Scientific Research and Technological Applications (SRTA-City), Alexandria 21934, Egypt t.h.taha@gmail.com

5 Composite and Nanostructured Materials Research Department, Advanced Technology and New Materials Research Institute, City of Scientific Research and Technological Applications (SRTA-City), Alexandria 21934, Egypt; mnano2050@yahoo.com

6 Chemistry Department, Faculty of Science, Alexandria University, Alexandria 21568, Egypt; emanawad473@gmail.com

7 Prince Sultan Bin Abdulaziz Center for Environmental and Tourism Research and Studies, King Khalid University (KSA), Abha 62529, Saudi Arabia

8 Department of Pathology, College of Medicine, King Khalid University, Abha 9004, Saudi Arabia; amalemam@kku.edu.sa

9 Department of Forensic Medicine and Clinical Toxicology, Faculty of Medicine, Mansoura University, Mansoura 35516, Egypt

* Correspondence: mfmostfa@kku.edu.sa

Abstract: $\mathrm{k}$-carrageenan is useful for its superior gelling, hydrogel, and thickening properties. The purpose of the study was to maximize the hydrogel properties and water-absorbing capacity of $\mathrm{k}$-carrageenan by blending it with starch from potato peels to be used as safe and biodegradable waterabsorbent children's toys. The prepared materials were analyzed using FTIR and Raman spectroscopy to analyze the functional groups. Results showed that there was a shift in the characteristic peaks of starch and $\mathrm{k}$-carrageenan, which indicated their proper reaction during blend formation. In addition, samples show a peak at $1220 \mathrm{~cm}^{-1}$ corresponding to the ester sulfate groups, and at $1670 \mathrm{~cm}^{-1}$ due to the carbonyl group contained in D-galactose. SEM micrographs showed the presence of rough surface topology after blending the two polymers, with the appearance of small pores. In addition, the presence of surface cracks indicates the biodegradability of the prepared membranes that would result after enzymatic treatment. These results are supported by surface roughness results that show the surface of the $\mathrm{k}$-carrageenan/starch membranes became rougher after enzymatic treatment. The hydrophilicity of the prepared membranes was evaluated from contact angle (CA) measurements and the swelling ratio. The swelling ratio of the prepared membranes increased gradually as the starch ratio increased, reaching $150 \%$, while the water-uptake capacity increased from $48 \pm 4 \%$ for plain $\mathrm{k}$-carrageenan to $150 \pm 5 \%$ for 1:2 $\mathrm{k}$-carrageenan/starch blends. The amylase enzyme showed an effective ability to degrade both the plain $\mathrm{k}$-carrageenan and $\mathrm{k}$-carrageenan/starch membranes, and release glucose units for up to 236 and 563, respectively. According to these results, these blends could be effectively used in making safe and biodegradable molded toys with superior water-absorbing capabilities. 
Keywords: k-carrageenan/starch blend; hydrogel; instrumental analysis; biodegradability; children's toys

\section{Introduction}

Hydrogels are commonly used for bio-fabrication, as they are biocompatible materials $[1,2]$. Historically, natural hydrogels have been commonly used for tissue engineering, including alginate, collagen, gelatin, and $\mathrm{k}$-carrageenan [3]. $\mathrm{k}$-carrageenan is a generic name for a family of water-soluble, sulfated polysaccharides present in the cell walls of members of the Gigartinales and used extensively as gels and thickeners in the food industry. According to research on their biodegradability, they can be disintegrated and broken down into carbon dioxide and water by microorganisms under humid conditions [4]. They have a great potential to be used in the future as packaging materials, cutlery, diapers, etc. [5].

$\mathrm{K}$-carrageenan is a family of polysaccharides extracted from a specific red seaweed species in the Rhodophyceae family, formed by alternate units of D-galactose and 3,6-anhydrogalactose (3,6-AG) joined by 1,3 and $\beta$-1,4-glycosidic linkage. $\mathrm{k}$-carrageenan has the ability to form gels and membranes with better mechanical properties [6,7]. It has been known for its superior water-absorbing capacity, which allows it to be used for various medical [8], electrochemical [9], food, and environmental applications [10].

Starch is an inexpensive and readily available material that is produced from renewable resources and can be efficiently used [6,11,12]. It has been previously applied in many industries, such as pharmaceuticals, paper, textiles, and the food industry [13,14], and can be applied by many companies as a hydrogel material [15]. Among the various starch sources, wasted starch from potato peels is considered an economical source of starch [16], which could be used in many applications, such as enzyme production [17].

Starch comprises linear amylose and branched amylopectin structures. Amylose is composed of $\alpha-1,4$ glucose units. This moiety supports the ability for film-forming. Starch-based films are often brittle and present weak mechanical properties. Therefore, starch can be mixed with other polymers to produce blends with excellent mechanical traits after solvent evaporation. Polymer blending is a well-used strategy whenever a change or improvement of properties is necessary. Starch-based films were created by blending starch with gelatin [18], lignocellulose nanofibers [19], chitosan [20], and biodegradable poly (vinyl alcohol) (PVA) [21].

Few studies have reported on starch/K-carrageenan blends. K-carrageenan has a linear sulfated structure obtained from red seaweed. It is composed of D-galactose and 3,6-anhydro-D-galactose units linked by $\alpha-1,3$ and $\beta-1,4$-glycosidic linkages. $\mathrm{k}$-carrageenan has gelling and film-forming features. These traits allow the production of biodegradable films [22].

The aims of the present work were to develop blends composed of mixtures of $\mathrm{k}$-carrageenan and starch to make safe and biodegradable molded toys as a novel application. $\mathrm{k}$-carrageenan was combined at a high temperature with various percentages of starch in the presence of glycerol to form a viscous liquid solution that can be poured into a mold, cooled at room temperature till complete solidification, and finally reshaped using shaped molds (for example, animal-shaped molds). An evaluation was carried out by analyzing the films' mechanical and swelling properties, these being the chemical interactions between the two polysaccharides, assessed by Fourier-transform infrared (FTIR) spectra, Raman spectra, and a scanning electron microscope (SEM). In addition, the hydrophilicity of the prepared membranes was evaluated from contact angle (CA) and water uptake (WU) measurements, and their potential biodegradability was also studied. 


\section{Materials and Methods}

\subsection{Materials}

K-carrageenan was obtained from Across Organics, and the $\alpha$-amylase enzyme $(700 \mathrm{U} / \mathrm{mL})$ was purchased from Sigma-Aldrich(St. Louis, MO, USA). RPI Glycerol Liquid, USP grade, and molecular weight (92.1).

\subsection{Extraction of Potato Peel Starch}

The potato peels, which were collected from different restaurants in Borg El-arab city, were washed with tap water, then cut into $1 \times 1 \mathrm{~cm}$ square pieces. The formed pieces were submerged in tap water and homogenized using a kitchen blender, then sieved using stainless-steel mesh (kitchen stainless steel sieve with filter sifter). The obtained large particles were discarded, while the starch-containing filtrate was left at room temperature till full evaporation of its water content. The dried starch molecules were collected, ground, and kept in a dry place till use.

\subsection{Preparation of $\kappa$-Carrageenan and $\kappa$-Carrageenan/Starch Blend}

$\mathrm{K}$-carrageenan solution ( $5 \%$ ) was prepared by dissolving in boiling water. Starch solution was prepared by dispersing varying proportions (2.5-10\%) of starch in distilled water. Blended solutions were prepared by mixing their pre-prepared solutions while stirring at $80^{\circ} \mathrm{C}$ to obtain $\mathrm{k}$-carrageenan/starch blends at different ratios of 2:1, 1:1, and 1:2 with dropwise addition of glycerol $(50 \mu \mathrm{m})$, which make membranes more elastic and enhances their mechanical characteristics. The prepared solutions were cast in a dolphin-shaped mold and kept at $27^{\circ} \mathrm{C}$ for $48 \mathrm{~h}$ under $35 \%$ humidity (Figure 1). It is worth mentioning that dried membrane from each $\mathrm{k}$-carrageenan/starch blend was prepared in order to facilitate their characterization process. In addition, the chemical structure of $\mathrm{k}$-carrageenan and starch can be shown in Scheme 1.

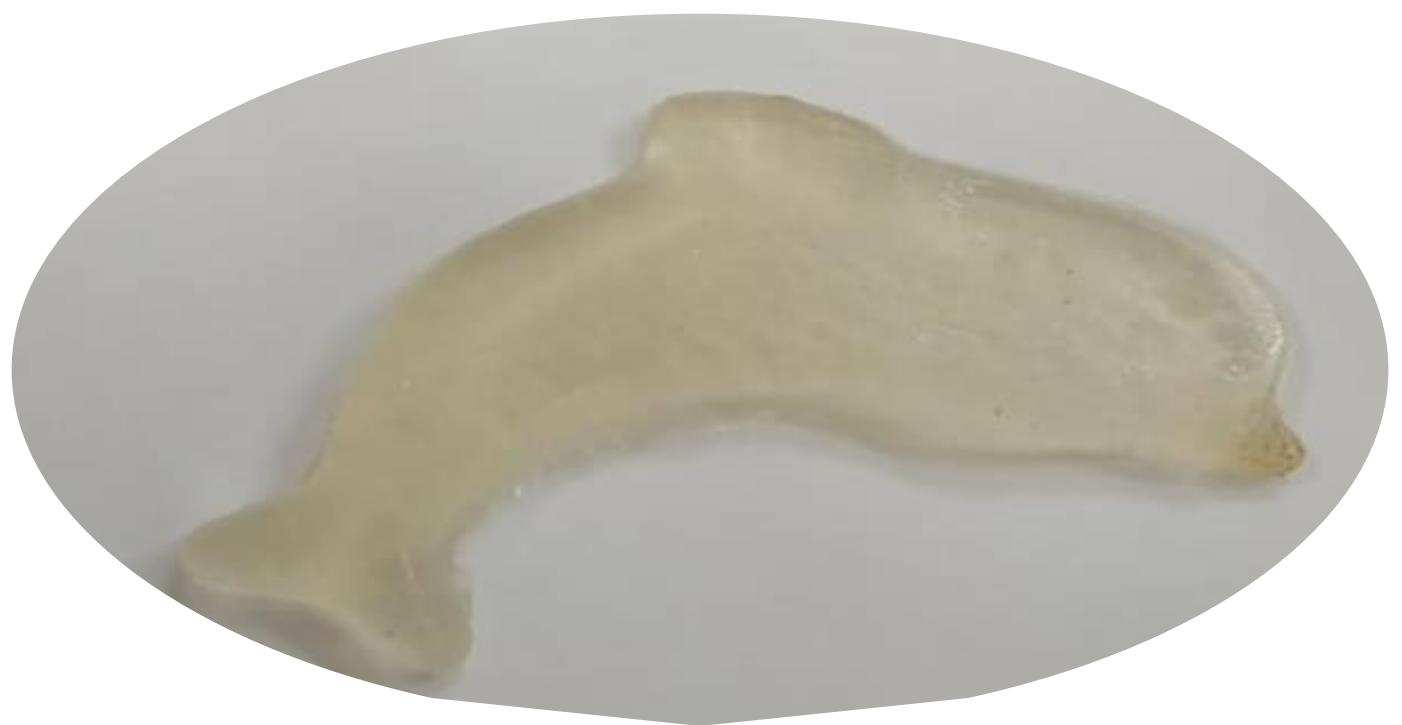

Figure 1. Dolphin gel formed by the blending of Carr/starch blend with superior water-absorbing capability. 


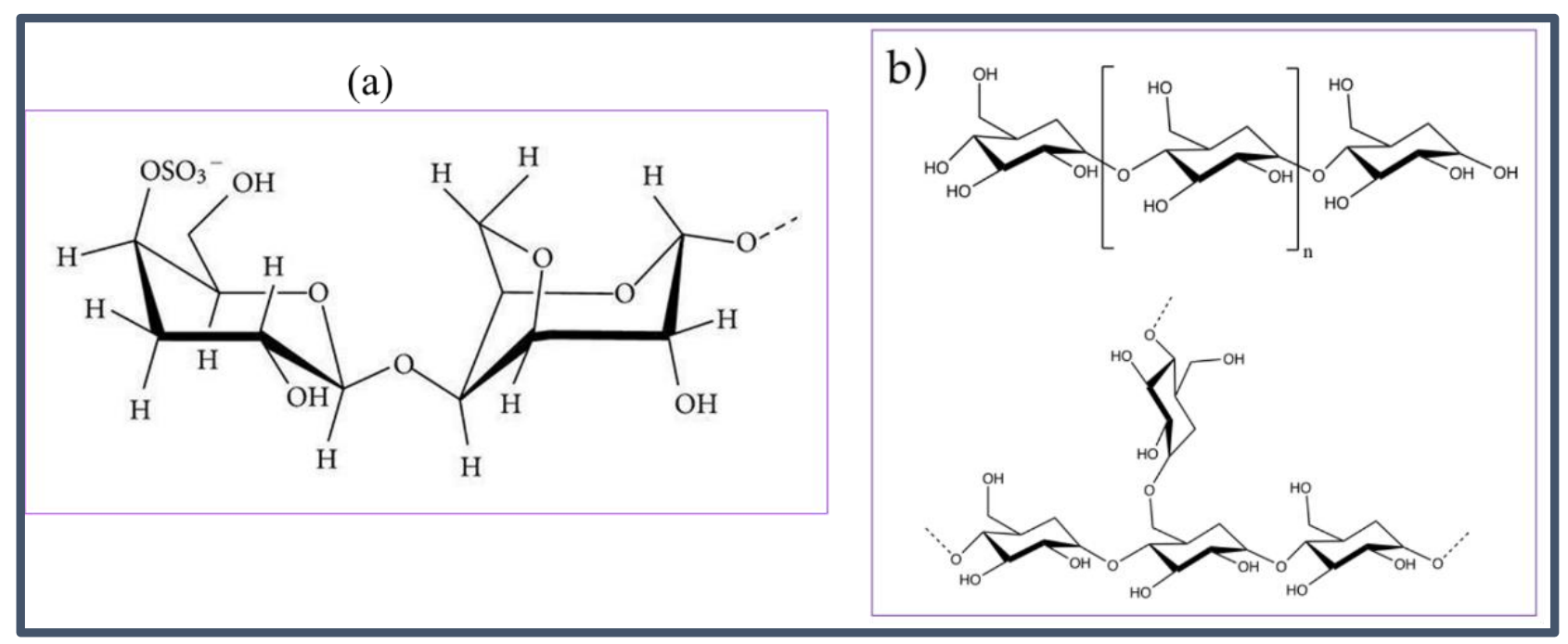

Scheme 1. Chemical structure of k-carrageenan (a) and starch (b).

\subsection{Characterization}

$\mathrm{K}$-carrageenan and $\mathrm{k}$-carrageenan/starch blend were characterized via several characterization methods, described as:

\subsubsection{Structural Characterization}

The presence of the functional groups of both mixed and individual polymers was verified by Fourier-transform infrared (FTIR) technique (Shimadzu FTIR-8400 S, Japan) [23] and Raman scattering spectrometer (SENTERRA-Bruker, Ettlingen, Germany) [24]. The surface morphology of prepared k-carrageenan, starch, and k-carrageenan/starch membranes was observed using SEM (JEOL JSM-6360LA, Tokyo, Japan) [25]. Specimens of the resultant membranes were examined at an acceleration voltage of $10 \mathrm{KV}$. The surface roughness of all prepared membranes was determined using a surface roughness meter (SJ-201P, Kawasaki, Japan) [26,27].

\subsubsection{Water Uptake, Swelling Ratios, and Water Contact Angle}

Water uptake of the prepared membranes was measured by the change in the weight between the wet $\left(W_{w}\right)$ and dry $\left(W_{d}\right)$ samples at $27^{\circ} \mathrm{C}$, as shown in the following equation [28].

$$
W U=\frac{W_{w}-W_{d}}{W_{d}} \times 100
$$

The swelling ratio of the membranes was estimated by the difference between the wet and dry dimensions of the length or thickness, which can be calculated by

$$
S R=\frac{L_{w}-L_{d}}{L_{d}} \times 100
$$

where $L_{w}$ and $L_{d}$ are the length of the wet and dry membranes, respectively.

The hydrophilicity of the prepared membranes was evaluated from contact angle (CA) measurements [29]. For each sample, CA was measured at room temperature using an optical system comprised of a zoom video lens (Ramé-Hart Instrument Goniometer, model 500-F1, Netcong, NJ, USA) connected to a charge-coupled device (CCD) camera operated via software. Contact angle was determined using Image J software $(1.47 \mathrm{v})$ with the plug-in drop shape analysis. Small drops $(\sim 2 \mu \mathrm{L})$ were manually deposited using a precision microliter pipette $[30,31]$.

The tensile strength of the polymer electrolyte membranes was measured using a Universal Testing Machine (Shimadzu UTM, Kyoto, Kyoto, Japan) at room temperature. 
The specimens were $50 \times 10 \mathrm{~mm}$. Measurements were carried out at a constant speed of cross heads movement $5 \mathrm{~mm} /$ minute. Three measurements were taken for each sample, and the mean values were considered [32].

\subsubsection{In Vitro Testing of Biodegradability}

This test has been performed according to with some modifications. The biodegradability of the prepared membranes was investigated through the incubation of $0.07 \mathrm{~g}$ of each membrane with $100 \mu \mathrm{L}$ amylase enzyme in $1400 \mu \mathrm{L}$ acetate buffer (pH 5.5). After $72 \mathrm{~h}$ incubation at $30{ }^{\circ} \mathrm{C}$ and $150 \mathrm{rpm}$, SEM, Raman spectroscopy, and FT-IR analysis were investigated using the solid residuals of each membrane. On the other hand, the concentration of the liberated glucose units was determined spectrophotometrically using glucose kit (Bio-System, Barcelona, Spain).

\section{Results and Discussion}

\subsection{FTIR Spectra}

Infrared spectroscopy is an effective method commonly used for polysaccharide characterization to study molecular interactions distinguished by the change of absorption bands. The fingerprint region of typical spectra of $\mathrm{k}$-carrageenan is presented in Figure 2A. The broad band ranging between 3500 and $3100 \mathrm{~cm}^{-1}$ was attributed to O-H stretching vibrations, formed due to the vibrational stretching associated with free inter- and intra- molecular bonds in -OH groups [19], and the broad band around $2800-3000 \mathrm{~cm}^{-1}$ was attributed to $\mathrm{C}-\mathrm{H}$ stretching vibration. Samples also show a band in the region of $750-1300 \mathrm{~cm}^{-1}$ that corresponds to the carbohydrates region [17,33]. The peak at $1220 \mathrm{~cm}^{-1}$ corresponds to the ester sulfate groups, and the peak at $1670 \mathrm{~cm}^{-1}$ is due to the carbonyl group contained in D-galactose [33]. Additionally, the FTIR spectra of starch typically show an extremely broad band at $3387 \mathrm{~cm}^{-1}$, and the band at $2930 \mathrm{~cm}^{-1}$ is attributed to the $\mathrm{O}-\mathrm{H}$ stretching and the $\mathrm{C}-\mathrm{H}$ stretching vibrations, respectively [34], as shown in Figure 2A. Meanwhile, the spectrum of carr/starch blend-based membranes shows stretching at $1200-1300 \mathrm{~cm}^{-1}$. Shifting of bands in this region is due to interactions between the charged functional groups of the $\mathrm{C}-\mathrm{O}$ stretching band and the $\mathrm{C}-\mathrm{O}-\mathrm{H}$ group band from $1162 \mathrm{~cm}^{-1}$ ( $\mathrm{k}$-carrageenan) to $1151 \mathrm{~cm}^{-1}$ ( $\mathrm{k}$-carrageenan/starch 2:1) that can be related to the interaction (possibly through hydrogen bridges) of the $\mathrm{OH}$ groups of starch with the K-carrageenan structure [35]. On the other hand, as shown in Figure 2B, after treatment of $\mathrm{K}$-carrageenan/starch membranes with an amylase enzyme, distinct peaks were visible at 3190-3380 $\mathrm{cm}^{-1}(\mathrm{~s})$, due to N-H stretching of secondary amides, and $2980 \mathrm{~cm}^{-1}$, due to $\mathrm{C}-\mathrm{H}$ stretching of the amylase enzyme, in addition to the characteristic peaks of K-carrageenan/starch membrane that appeared [36].

\subsection{Raman Scattering Spectra}

Raman spectroscopy results confirmed the interactions of starch with k-carrageenan. Figure 3A shows the Raman spectra of starch, $\mathrm{k}$-carrageenan, and $\mathrm{k}$-carrageenan/starch membranes. The starch spectrum exhibited three characteristic scattering peaks at 1263 , 1053 , and $941 \mathrm{~cm}^{-1}$, which are due to the stretching of C-O, C-C, and C-OH bonds belonging to starch [37]. Absorption at $2812 \mathrm{~cm}^{-1}$ was due to the $\mathrm{C}-\mathrm{H}$ stretching. Absorption at $1238 \mathrm{~cm}^{-1}$ was due to the ester sulfate group, and absorption at $1048 \mathrm{~cm}^{-1}$ was due to glycosidic linkage $[38,39]$. However, the $\mathrm{k}$-carrageenan/starch blend resulted in the appearance of a new peak at $1700 \mathrm{~cm}^{-1}$, which was due to the formation of the carbonyl group. This peak was initially thought to have resulted from the oxidation of carbohydrate radicals generated inside the $\mathrm{k}$-carrageenan polymer. However, as shown in Figure $3 \mathrm{~B}$, after enzymatic treatment, the characteristic peak of $\mathrm{k}$-carrageenan/starch membranes appeared as an additional peak at $3434 \mathrm{~cm}^{-1}$ due to $\mathrm{NH}_{2}$ stretching, which confirms the effect of the amylase enzyme on the degradation of the membranes $[36,40]$. 

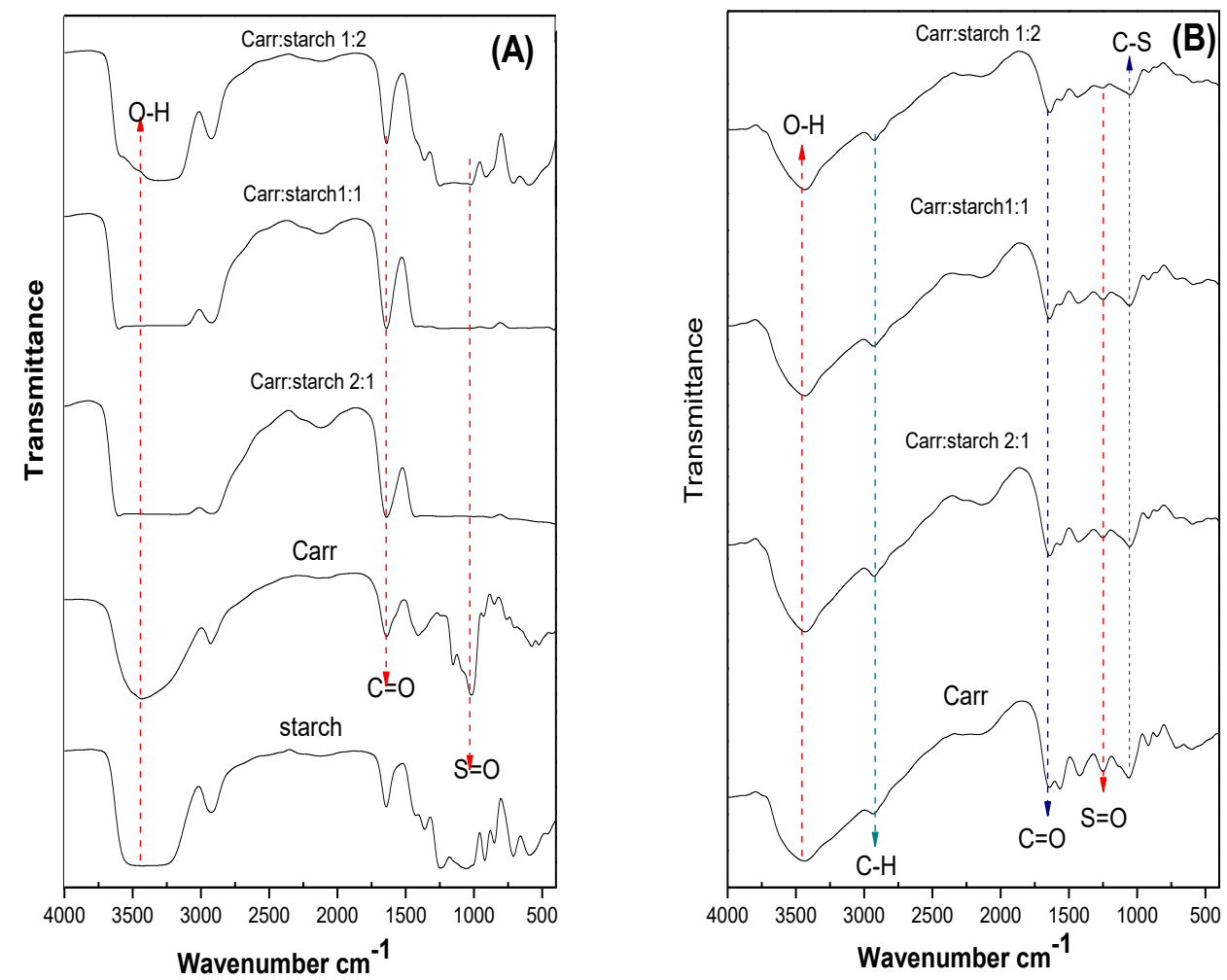

Figure 2. FTIR spectra of Carr, starch, and Carr/starch blend-based membranes before enzymatic treatment (A) and after enzymatic treatment $(\mathbf{B})$.
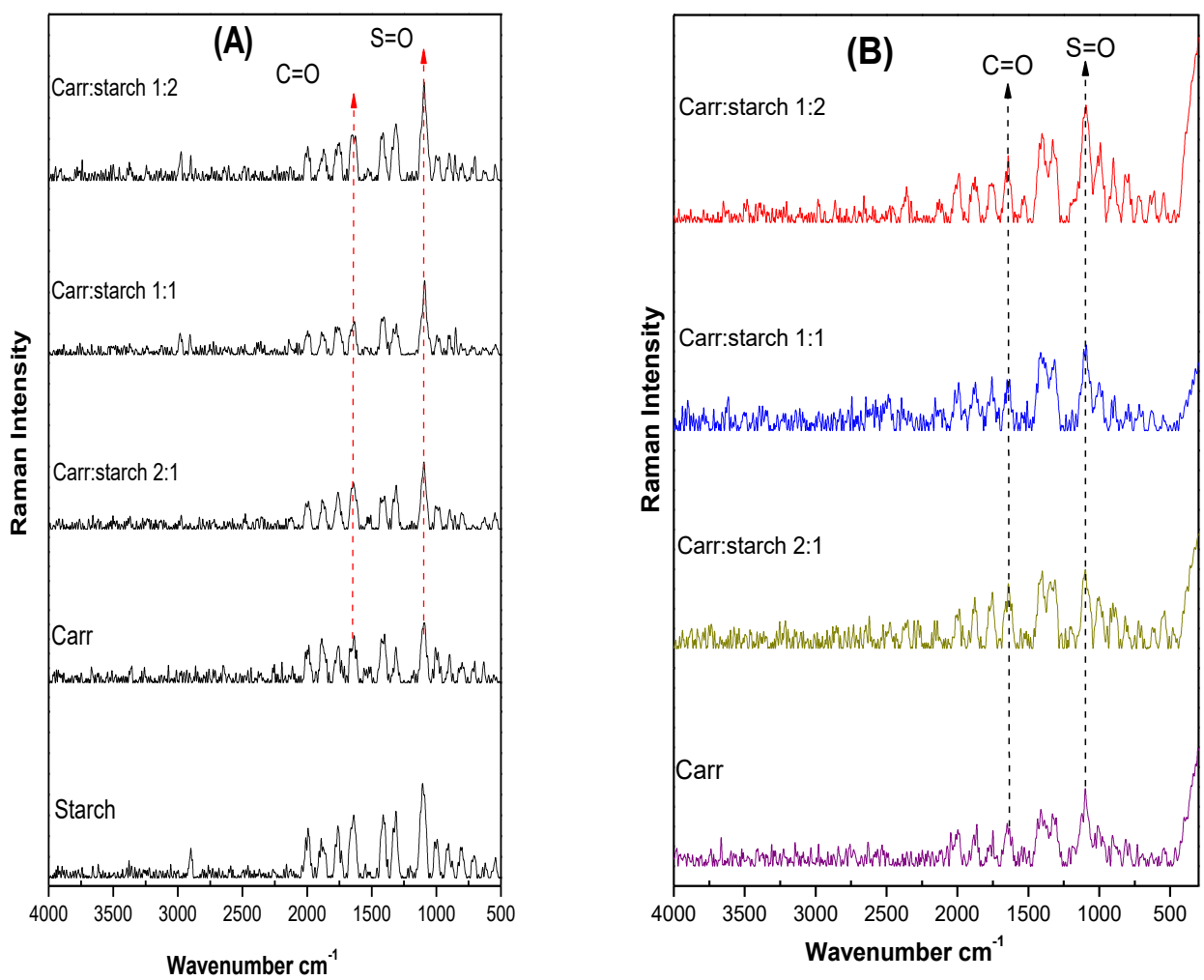

Figure 3. Raman scattering spectra of $\mathrm{K}$-carrageenan, starch, and Carr/starch blend-based membranes before (A) and after (B) treatment with amylase enzyme. 


\subsection{In Vitro Biodegradability Test}

The investigation of the membranes' biodegradability was dependent on the ability of the amylase enzyme to release glucose units from these membranes. As shown in Figure 4, higher concentrations of glucose were obtained from the three tested membranes ( $\mathrm{k}$-carrageenan/starch 1:1, $\mathrm{k}$-carrageenan/starch 2:1, and $\mathrm{k}$-carrageenan/starch $1: 2)$ in addition to lower glucose concentration from the plain $k$-carrageenan membrane. The glucose concentration was almost 563,548 , and $540.5 \mathrm{mg} / \mathrm{dL}$ for the three mixed $\mathrm{k}$-carrageenan/starch membranes, respectively. However, the amylase enzyme showed an ability to degrade the $\mathrm{k}$-carrageenan polymer, and released $236 \mathrm{mg} / \mathrm{dL}$ glucose. In most cases, using pure enzymes for the biodegradation of waste is preferred over using whole living microbes due to their greater catalytic activity and the absence of seasonal fluctuations [41]. However, the use of soil microbes for the biodegradation of potato peel starch depending on hydrogel was investigated through soil burying of the prepared materials [42].

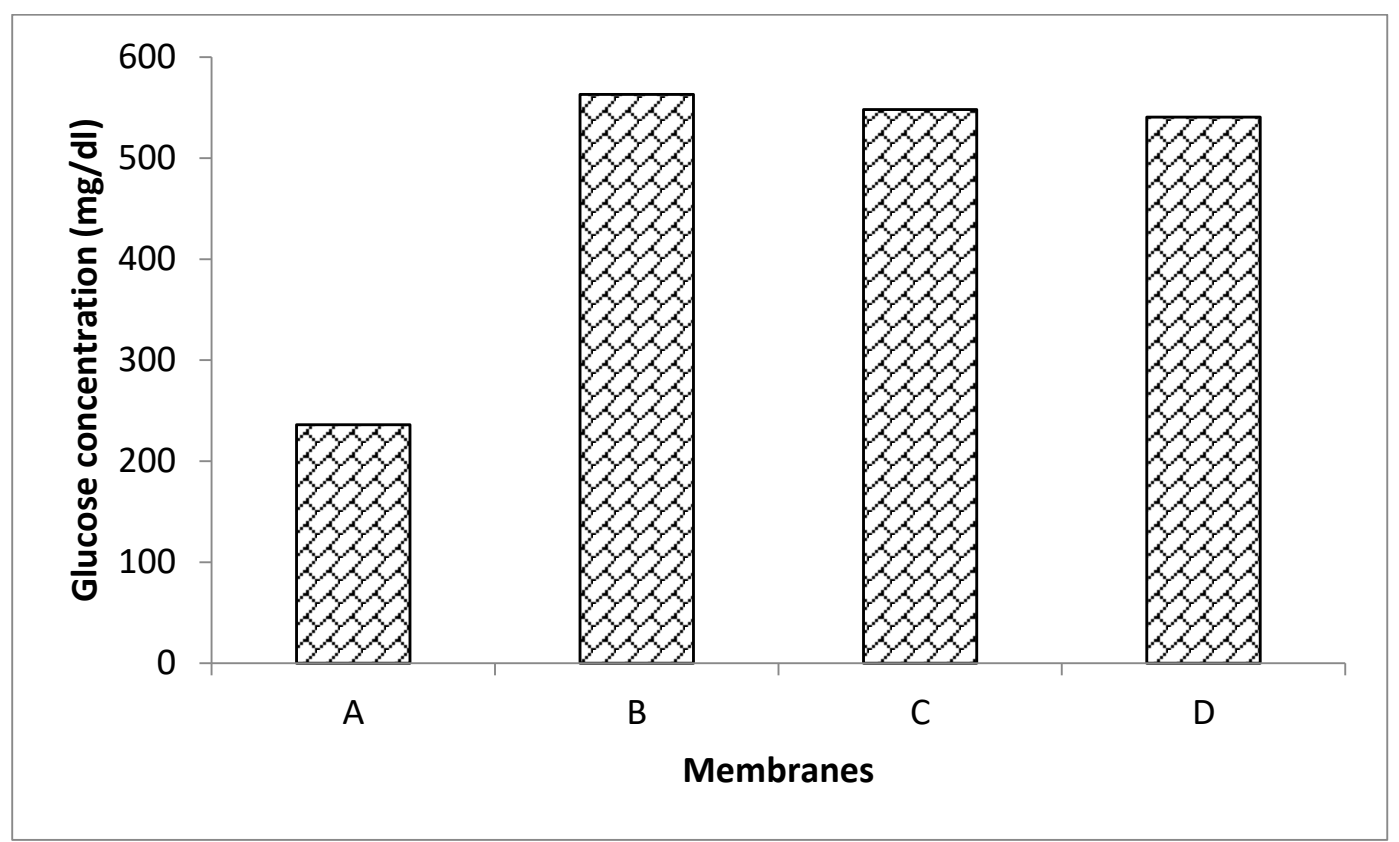

Figure 4. Concentration of glucose units released through the biodegradation of $\mathrm{k}$-carrageenan-starch membranes using amylase enzyme. (A): plain k-carrageenan, (B): K-carrageenan: starch (1:1), (C): K-carrageenan: starch (2:1), and (D): k-carrageenan: starch (1:2).

\subsection{SEM Micrograph}

SEM microphotographs of starch granules, as well as the surface of the k-carrageenan/starch membranes are shown in Figure 5. The starch granules appeared oval, large, with compact and smooth surfaces [43]. On the other hand, the k-carrageenan surface appeared as a homogenous membrane surface with no gross defects. Meanwhile, the presence of rough surface topology after blending starch and $\mathrm{k}$-carrageenan, and the appearance of small pores, indicate the presence of starch granules and the interaction of starch and $\mathrm{k}$ carrageenan. As represented in Figure 5A, membrane roughness proportionally increased as the concentration of starch was increased, and the membranes appeared without phase separation, which indicates a good interaction between the components, as confirmed by FTIR and Raman spectroscopy [44]. After enzymatic treatment, it was noticed that multiple cracks were shown on each membrane surface. These cracks grew as the starch concentration was increased, which indicates the potent ability of the enzyme to degrade the tested membranes. These data are strongly supported by the concentration of glucose 
that was released after the enzymatic treatment of the membranes (Figure 4). In addition, the existence of cracks indicates the membranes' biodegradability.

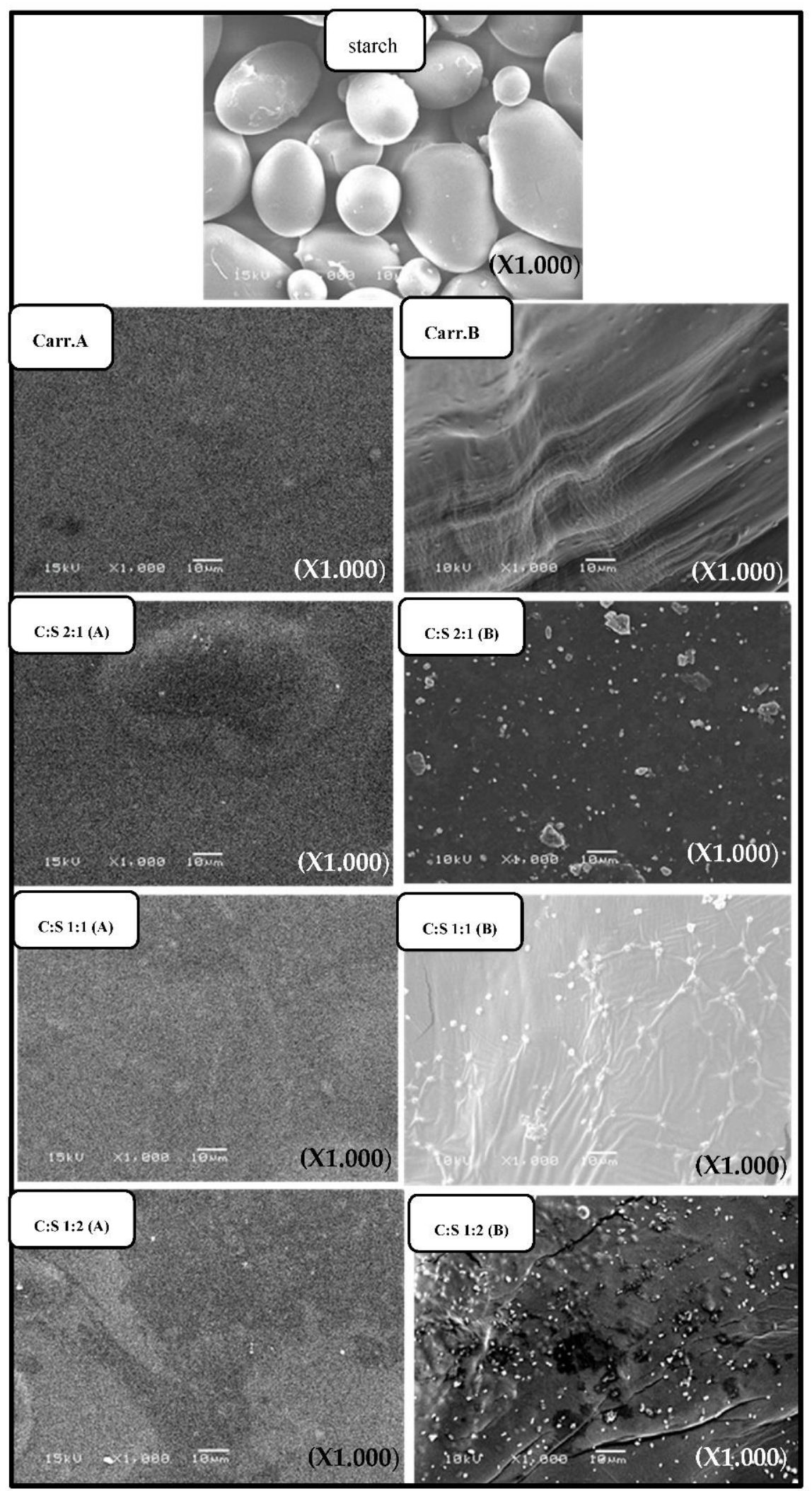

Figure 5. SEM micrograph of surface of starch, Carr, and Carr/starch blend-based membranes before (A) and after (B) enzymatic treatment at magnification power of $1000 \times$. 


\subsection{Surface Roughness}

Surface roughness values of the $k$-carrageenan and $k$-carrageenan/starch membranes with different ratios before and after enzymatic treatment are shown in Table 1 . The surface roughness of the plain $\mathrm{k}$-carrageenan membrane was the lowest value $(0.25 \mu \mathrm{m})$. This value was affected by blending $\mathrm{k}$-carrageenan with starch, especially k-carrageenan/starch (1:2), which showed the highest value $(1.1 \mu \mathrm{m})$. After enzymatic treatment, as represented in Table 1, the surface of the $\mathrm{k}$-carrageenan/starch membranes with different ratios increased in roughness, which indicates the effective degradation of the membranes by the amylase enzyme. These results are supported by the SEM images (Figure 5B).

Table 1. Surface roughness values of Carr/starch membranes before (A) and after (B) enzymatic treatment.

\begin{tabular}{ccc}
\hline Sample & Roughness $(\boldsymbol{\mu m}) \mathbf{( A )}$ & Roughness $(\boldsymbol{\mu m})(\mathbf{B})$ \\
\hline Carr & $0.25 \pm 0.02$ & $0.50 \pm 0.05$ \\
Carr: starch 2:1 & $0.49 \pm 0.05$ & $0.87 \pm 0.03$ \\
Carr: starch 1:1 & $0.82 \pm 0.04$ & $1.11 \pm 0.07$ \\
Carr: starch 1:2 & $1.1 \pm 0.03$ & $1.57 \pm 0.08$ \\
\hline
\end{tabular}

\subsection{Water Uptake and Contact Angle}

Water uptake of the $\mathrm{k}$-carrageenan/starch membranes increased gradually as the starch ratio increased. As shown in Table 2A, the pristine $\mathrm{k}$-carrageenan showed the lowest swelling ratio, of around $48 \%$ [15], much lower than the starch-conjugated counterparts, which showed changes of between 70 and $150 \%$. Furthermore, the high absorption of $\mathrm{K}$-carrageenan/starch could minimize the chances of phase separation, thus improving the permeability properties of the membrane. As shown in Table 2B, after enzymatic treatment, the swelling degree increased to reach $180 \%$ for the $\mathrm{k}$-carrageenan/starch (1:2) membrane. The increments of water uptake after the enzymatic treatment revealed the potency of amylase enzyme degradability, as the membrane degradation resulted in the increased porosity of the membranes' surfaces, which allowed more water molecules to penetrate the matrix, resulting in an increased water uptake percentage. These data indicate the effect of the enzyme on the tested membranes and are good evidence for the potential of the prepared membranes as biodegradable plastic.

Table 2. Water uptake and swelling ratio values of Carr/starch membranes before (A) and after (B) enzymatic treatment.

\begin{tabular}{ccccc}
\hline Sample & SR\%(A) & WU\% (A) & WU\% (B) & SR\% (B) \\
\hline Carr & $33.41 \pm 2$ & $48 \pm 4$ & $60 \pm 5$ & $40.21 \pm 2$ \\
Carr: starch 2:1 & $40.14 \pm 3$ & $70 \pm 2$ & $78 \pm 3$ & $51.36 \pm 1$ \\
Carr: starch 1:1 & $42.11 \pm 2$ & $90 \pm 4$ & $110 \pm 2$ & $60.11 \pm 0.5$ \\
Carr: starch 1:2 & $54.35 \pm 5$ & $150 \pm 5$ & $180 \pm 4$ & $70.28 \pm 1$ \\
\hline
\end{tabular}

However, regarding the viscoelastic properties of the hydrogel: the gelation of $\kappa$-carrageenan has been widely studied using various methods, such as rheological experiments, to understand the properties of the mixed carrageenan gels.

The viscoelastic behavior of $\mathrm{K}$-carrageenan reveals a fluid-like character. At $9{ }^{\circ} \mathrm{C}$, $\kappa$-carrageenan molecules are in the ordered state, but neither aggregation nor gelation takes place. Moreover, $\mathrm{k}$-carrageenan molecules being in the ordered state are obviously stiffer than in the disordered one.

In cases where $\mathrm{k}$-carrageenan is blended with starches, a synergistic effect on the rheological properties of the pastes and gels exists. Starch pastes and gels are considered a biphasic system, with the continuous phase consisting of the solvent and dissolved starch during gelatinization, and a disperse phase consisting of swollen granules. This viewpoint emphasizes the presence of swollen particles in starch suspensions. The swollen granules are not only deformable, but also compressible and elastic. 
On the other hand, the hydrophilic/hydrophobic nature of the membranes' surfaces is often indicated by the contact angle. Water contact angle values of the prepared membranes are listed in Table 3. Generally, the contact angle of $\mathrm{k}$-carrageenan membranes decreased with the addition of starch, from $84 \theta$ to within a range of 70 to $60 \theta$ (Table 3A). This decrement was more pronounced after enzymatic treatment [45]. The enzymatic treatment resulted in a decrease in the contact angle of $\mathrm{k}$-carrageenan to $70 \theta$. The contact angle was significantly decreased to between 60 and $35 \theta$ with different starch ratios (Table 3B). According to these results, the $\mathrm{K}$-carrageenan/starch membranes can be effectively used as an improved hydrogel that can be projected to replace synthetic plastics.

Table 3. Water contact angle values of Carr/starch membranes before (A) and after (B) enzymatic treatment.

\begin{tabular}{lcc}
\hline \multicolumn{1}{c}{ Sample } & Mean Theta $\boldsymbol{\theta}$ (A) & Mean Theta $\boldsymbol{\theta}$ (B) \\
\hline Carr & $84 \pm 3$ & $70 \pm 5$ \\
Carr: starch 2:1 & $70 \pm 2$ & $60 \pm 5$ \\
Carr: starch 1:1 & $65 \pm 4$ & $45 \pm 2$ \\
Carr: starch 1:2 & $60 \pm 5$ & $35 \pm 2$ \\
\hline
\end{tabular}

\subsection{Tensile Strength}

The tensile strength and elongation at break for the prepared membranes are given in Table 4. When starch concentration in the blend formulation was increased, the tensile strength increased from 5.61 of plain Carr to 10.11 MPa at Carr/starch (1:1), which was recorded as the maximum measurement. However, the elongation at break decreased with the increasing concentration of starch. This could be due to the proper initiation of intermolecular interactions between the Carr polymer and the starch present in the system.

Table 4. Mechanical properties of Carr and Carr/starch membranes.

\begin{tabular}{lcc}
\hline \multicolumn{1}{c}{ Sample } & Tensile Strength $\mathbf{( M P a )}$ & Elongation at Break (mm) \\
\hline Carr & $5.61 \pm 2$ & $5.34 \pm 2$ \\
Carr: starch 2:1 & $7.24 \pm 1$ & $3.11 \pm 1$ \\
Carr: starch 1:1 & $10.11 \pm 3$ & $2.01 \pm 0.5$ \\
Carr: starch 1:2 & $4.35 \pm 1$ & $1.80 \pm 1$ \\
\hline
\end{tabular}

\section{Conclusions}

Blends of $\mathrm{k}$-carrageenan and potato peel starch were prepared in three different ratios. Both polymers were characterized before and after blending, using SEM, FTIR, Raman, etc., in addition to testing their biodegradability through enzymatic treatment. The results provide useful information on the structural properties of $k$-carrageenan and starch and the structural changes in the network induced when mixing different ratios of the two polysaccharides, before and after enzymatic treatment. The FTIR spectra of $k$-carrageenan/starch blend-based membranes showed stretching and shifting of different bands that can be related to their interaction. Additionally, SEM showed the presence of rough surface topology after the blending of starch and $\mathrm{k}$-carrageenan, indicating the presence of starch granules and the interaction of starch and $\mathrm{k}$-carrageenan. After enzymatic treatment, multiple cracks were noticed on each membrane surface, indicating potent enzymatic degradation of the prepared membranes. The swelling ratio and water contact angle results of the K-carrageenan/starch membranes illustrate hydrophilic properties that increased gradually as the starch ratio increased. However, after enzymatic treatment, the swelling degree increased to reach $180 \%$ for the $\mathrm{k}$-carrageenan/starch (1:2) membrane due to the increased porosity of the membranes' surfaces, which allowed more water molecules to penetrate the matrix. According to these results, it is proposed that $\mathrm{k}$-carrageenan/starch blends can be effectively used as a super-absorbent hydrogel that can be used as biodegradable children's toys. 
Author Contributions: Conceptualization, M.A.A.-S. and T.H.T.; methodology, M.E.; software, E.A.E.D.; validation, M.A.-K. and M.M.; formal analysis, M.M.; investigation, S.A. (Saad Alamri); resources, S.A. (Sulaiman Alrumman); data curation, M.A.A.-S., T.H.T. and M.M.; writing-original draft preparation, M.A.-K. and A.A.-E.; writing-review and editing, H.A., A.S., A.A.-E. and R.A.-Q.; visualization, M.M. and A.A.-E.; funding acquisition. All authors have read and agreed to the published version of the manuscript.

Funding: This research was supported by the Deanship of Scientific Research at King Khalid University under Grant no. (R.G.P. 1/244/42).

Institutional Review Board Statement: Not applicable.

Informed Consent Statement: Not applicable.

Data Availability Statement: All data are available in the main text.

Acknowledgments: Thanks to the Deanship of Scientific Research at King Khalid University, Saudi Arabia, for supporting this article.

Conflicts of Interest: The authors declare no conflict of interest.

\section{References}

1. Karana, E. Characterization of 'natural' and 'high-quality' materials to improve perception of bio-plastics. J. Clean. Prod. 2012, 37, 316-325. [CrossRef]

2. Sarasa, J.; Gracia, J.M.; Javierre, C. Study of the biodisintegration of a bioplastic material waste. Bioresour. Technol. 2009, 100, 3764-3768. [CrossRef] [PubMed]

3. Luengo, J.M.; García, B.; Sandoval, A.; Naharro, G.; Olivera, E.R. Bioplastics from microorganisms. Curr. Opin. Microbiol. 2003, 6, 251-260. [CrossRef]

4. El Kadi, S. Bioplastic Production form Inexpensive Sources Bacterial Biosynthesis, Cultivation System, Production and Biodegrability; VDM (Verlag Dr. Muller) Publishing House: New York, NY, USA, 2010.

5. Schulze, C.; Juraschek, M.; Herrmann, C.; Thiede, S. Energy analysis of bioplastics processing. Procedia CIRP 2017, 61, 600-605. [CrossRef]

6. Kaith, B.; Jindal, R.; Jana, A.; Maiti, M. Development of corn starch based green composites reinforced with Saccharum spontaneum L fiber and graft copolymers-Evaluation of thermal, physico-chemical and mechanical properties. Bioresour. Technol. 2010, 101, 6843-6851. [CrossRef]

7. Anjum, A.; Zuber, M.; Zia, K.M.; Noreen, A.; Anjum, M.N.; Tabasum, S. Microbial production of polyhydroxyalkanoates (PHAs) and its copolymers: A review of recent advancements. Int. J. Biol. Macromol. 2016, 89, 161-174. [CrossRef]

8. Dafe, A.; Etemadi, H.; Zarredar, H.; Mahdavinia, G.R. Development of novel carboxymethyl cellulose/ $\mathrm{k}$-carrageenan blends as an enteric delivery vehicle for probiotic bacteria. Int. J. Biol. Macromol. 2017, 97, 299-307. [CrossRef]

9. Perumal, P.; Selvin, P.C. Red algae-derived K-carrageenan-based proton-conducting electrolytes for the wearable electrical devices. J. Solid State Electrochem. 2020, 24, 2249-2260. [CrossRef]

10. Venkatesan, R.; Rajeswari, N.; Thiyagu, T.T. Preparation, characterization and mechanical properties of $\mathrm{k}$-carrageenan/SiO 2 nanocomposite films for antimicrobial food packaging. Bull. Mater. Sci. 2017, 40, 609-614. [CrossRef]

11. Roldán-Carrillo, T.; Rodrıuez-Vázquez, R.; Diaz-Cervantes, D.; Vázquez-Torres, H.; Manzur-Guzmán, A.; Torres-Domınguez, A. Starch-based plastic polymer degradation by the white rot fungus Phanerochaete chrysosporium grown on sugarcane bagasse pith: Enzyme production. Bioresour. Technol. 2003, 86, 1-5. [CrossRef]

12. Ma, X.; Chang, P.R.; Yu, J.; Stumborg, M. Properties of biodegradable citric acid-modified granular starch/thermoplastic pea starch composites. Carbohydr. Polym. 2009, 75, 1-8. [CrossRef]

13. Naik, S.N.; Goud, V.V.; Rout, P.K.; Dalai, A.K. Production of first and second generation biofuels: A comprehensive review. Renew. Sustain. Energy Rev. 2010, 14, 578-597. [CrossRef]

14. Tupa, M.; Maldonado, L.; Vázquez, A.; Foresti, M.L. Simple organocatalytic route for the synthesis of starch esters. Carbohydr. Polym. 2013, 98, 349-357. [CrossRef] [PubMed]

15. Abdul Khalil, H.P.S.; Tye, Y.Y.; Saurabh, C.K.; Leh, C.P.; Lai, T.K.; Chong, E.W.N.; Nurul Fazita, M.R.; Mohd Hafiidz, J.; Banerjee, A.; Syakir, M.I. Biodegradable polymer films from seaweed polysaccharides: A review on cellulose as a reinforcement material. Express Polym. Lett. 2017, 11, 244-265. [CrossRef]

16. Torres, M.D.; Domínguez, H. Valorisation of potato wastes. Int. J. Food Sci. Technol. 2020, 55, 2296-2304. [CrossRef]

17. Mushtaq, Q.; Tabssum, F.; Qazi, J.I.; Irfan, M. Potato peels: A potential food waste for amylase production. J. Food Process. Eng. 2016, 40, 12512. [CrossRef]

18. Liu, B.; Zhu, S.; Zhong, F.; Yokoyama, W.; Huang, D.; Li, Y. Modulating storage stability of binary gel by adjusting the ratios of starch and kappa-carrageenan. Carbohydr. Polym. 2021, 268, 118264. [CrossRef]

19. Abdillah, A.A.; Charles, A.L. Characterization of a natural biodegradable edible film obtained from arrowroot starch and iota-carrageenan and application in food packaging. Int. J. Biol. Macromol. 2021, 191, 618-626. [CrossRef] 
20. Zhang, C.; Chi, W.; Meng, F.; Wang, L. Fabricating an anti-shrinking k-carrageenan/sodium carboxymethyl starch film by incorporating carboxylated cellulose nanofibrils for fruit preservation. Int. J. Biol. Macromol. 2021, 191, 706-713. [CrossRef] [PubMed]

21. Ta, L.P.; Bujna, E.; Antal, O.; Ladányi, M.; Juhász, R.; Szécsi, A.; Kun, S.; Sudheer, S.; Gupta, V.K.; Nguyen, Q.D. Effects of various polysaccharides (alginate, carrageenan, gums, chitosan) and their combination with prebiotic saccharides (resistant starch, lactosucrose, lactulose) on the encapsulation of probiotic bacteria Lactobacillus casei 01 strain. Int. J. Biol. Macromol. 2021, 183, 1136-1144. [CrossRef]

22. De Barizão, C.; Crepaldi, M.I.; de Oliveira, S.O.; de Oliveira, A.C.; Martins, A.F.; Garcia, P.S.; Bonafé, E.G. Biodegradable films based on commercial K-carrageenan and cassava starch to achieve low production costs. Int. J. Biol. Macromol. 2020, 165, 582-590. [CrossRef]

23. Abu-Saied, M.; Taha, T.H.; El-Deeb, N.M.; Hafez, E. Polyvinyl alcohol/Sodium alginate integrated silver nanoparticles as probable solution for decontamination of microbes contaminated water. Int. J. Biol. Macromol. 2018, 107, 1773-1781. [CrossRef]

24. Abu-Saied, M.A.; Elzatahry, A.A.; El-Khatib, K.M.; Hassan, E.A.; El-Sabbah, M.M.; Drioli, E.; Eldin, M.S.M. Preparation and characterization of novel grafted cellophane-phosphoric acid-doped membranes for proton exchange membrane fuel-cell applications. J. Appl. Polym. Sci. 2012, 123, 3710-3724. [CrossRef]

25. Abu-Saied, M.; Khalil, K.A.; Al-Deyab, S.S. Preparation and characterization of poly vinyl acetate nanofiber doping copper metal. Int. J. Electrochem. Sci. 2012, 7, 2019-2027.

26. Eldin, M.S.M.; Tamer, T.M.; Abu Saied, M.A.; Soliman, E.A.; Madi, N.K.; Ragab, I.; Fadel, I. Click grafting of chitosan onto PVC surfaces for biomedical applications. Adv. Polym. Technol. 2018, 37, 38-49. [CrossRef]

27. Samin, R.; Nuawi, M.; Haris, S.; Ghani, J. Statistical investigation for cutting force and surface roughness of S45C steel in turning processes by I-kazTM method. In Journal of Physics: Conference Series; IOP Publishing: Bristol, UK, 2020; p. 012028.

28. Abu-Saied, M.; El-Desouky, E.; Soliman, E.; El-Naim, G.A. Novel sulphonated poly (vinyl chloride)/poly (2-acrylamido-2methylpropane sulphonic acid) blends-based polyelectrolyte membranes for direct methanol fuel cells. Polym. Test. 2020, 89, 106604. [CrossRef]

29. Zhao, S.; Tsen, W.-C.; Hu, F.; Zhong, F.; Liu, H.; Wen, S.; Zheng, G.; Qin, C.; Gong, C. Layered double hydroxide-coated silica nanospheres with 3D architecture-modified composite anion exchange membranes for fuel cell applications. J. Mater. Sci. 2020, 55, 2967-2983. [CrossRef]

30. Abu-Saied, M.; Soliman, E.; Desouki, E. Development of Proton Exchange Membranes Based on Chitosan Blended with Poly (2-Acrylamido-2-Methylpropane Sulfonic Acid) for Fuel Cells applications. Mater. Today Commun. 2020, 25, 101536. [CrossRef]

31. Nogalska, A.; Trojanowska, A.; Tylkowski, B.; Garcia-Valls, R. Surface characterization by optical contact anglemeasuring system. Phys. Sci. Rev. 2020, 5, 83.

32. Abu-Saied, M.; Soliman, E.A.; Abualnaj, K.M.; el Desouky, E. Highly Conductive Polyelectrolyte Membranes Poly (vinyl alcohol)/Poly (2-acrylamido-2-methyl propane sulfonic acid)(PVA/PAMPS) for Fuel Cell Application. Polymers 2021, 13, 2638. [CrossRef]

33. Pereira, L.; Gheda, S.F.; Ribeiro-Claro, P.J.A. Analysis by vibrational spectroscopy of seaweed polysaccharides with potential use in food, pharmaceutical, and cosmetic industries. Int. J. Carbohydr. Chem. 2013, 2013, 537202. [CrossRef]

34. Volery, P.; Besson, R.; Schaffer-Lequart, C. Characterization of commercial carrageenans by fourier transform infrared spectroscopy using single-reflection attenuated total reflection. J. Agric. Food Chem. 2004, 52, 7457-7463. [CrossRef]

35. Kizil, R.; Irudayaraj, J.; Seetharaman, K. Characterization of irradiated starches by using FT-Raman and FTIR spectroscopy. J. Agric. Food Chem. 2002, 50, 3912-3918. [CrossRef]

36. Hassan, M.E.; Yang, Q.; Xiao, Z. Covalent immobilization of glucoamylase enzyme onto chemically activated surface of K-carrageenan. Bull. Natl. Res. Cent. 2019, 43, 102. [CrossRef]

37. Thakur, R.; Saberi, B.; Pristijono, P.; Golding, J.; Stathopoulos, C.; Scarlett, C.; Bowyer, M.; Vuong, Q. Characterization of rice starch-ı-carrageenan biodegradable edible film. Effect of stearic acid on the film properties. Int. J. Biol. Macromol. 2016, 93, 952-960. [CrossRef] [PubMed]

38. Pereira, L. Identification of phycocolloids by vibrational spectroscopy. World Seaweed Resources-An Authoritative Reference System; ETI Information Services Ltd.: London, UK, 2006; pp. 1-22.

39. Pereira, L.; Amado, A.M.; Ribeiro-Claro, P.J.; van de Velde, F. Vibrational spectroscopy (FTIR-ATR and FT-Raman)-a rapid and useful tool for phycocolloid analysis. In Proceedings of the BIODEVICES 2009-Proceedings of the $2^{\circ}$ International Conference on Biomedical Electronics and Devices, Porto, Portugal, 14-17 January 2009.

40. Namdeo, M.; Bajpai, S. Immobilization of $\alpha$-amylase onto cellulose-coated magnetite (CCM) nanoparticles and preliminary starch degradation study. J. Mol. Catal. B Enzym. 2009, 59, 134-139. [CrossRef]

41. Kohlhepp, G. Análise da situação da produção de etanol e biodiesel no Brasil. Estudos Avançados 2010, 24, 223-253. [CrossRef]

42. Arikan, E.B.; Bilgen, H.D. Production of bioplastic from potato peel waste and investigation of its biodegradability. Int. Adv. Res. Eng. J. 2019, 3, 93-97.

43. Sujka, M.; Jamroz, J. Ultrasound-treated starch: SEM and TEM imaging, and functional behaviour. Food Hydrocoll. 2013, 31, 413-419. [CrossRef]

44. Karthikeyan, S.; Selvasekarapandian, S.; Premalatha, M.; Monisha, S.; Boopathi, G.; Aristatil, G.; Arun, A.; Madeswaran, S. Proton-conducting I-Carrageenan-based biopolymer electrolyte for fuel cell application. Ionics 2016, 23, 2775-2780. [CrossRef]

45. Olímpio, F.; Mendes, A.A.; Trevisan, M.; Garcia, J. Preparation and Delayed Release Study on Pancreatin Encapsulated into Alginate, Carrageenan and Pectin Hydrogels. J. Braz. Chem. Soc. 2020, 31, 320-330. [CrossRef] 